\title{
Jürgen Moltmann e a noção de pathos divino
}

\author{
Jürgen Moltmann and the notion of divine pathos
}

Edson Fernando de Almeida

RESUMO

Este artigo tem como objetivo apresentar a noção de pathos divino em Jürgen Moltmann. Tal noção veio a Moltmann pelos escritos do teólogo e filosofo judeu Abraham Joshua Heschel. Para este, o pathos divino é a forma da presença de Deus no mundo, a preocupação divina com a sua criação. Os profetas não tinham ideias sobre Deus. Os profetas sofriam o pathos divino. Moltmann assumiu a noção de pathos hescheliana e, por meio dela, interpretou o drama pascal de Jesus de Nazaré. $\bigcirc$ pathos trinitário é o amor do Pai que se auto-humilha no Filho para, pelo Espírito, ser o Pai de todos os humilhados.

PALAVRAS-CHAVE: Pathos divino; Sofrimento; Teopatia.

ABSTRACT

This article aims to present to the notion of divine pathos in Jürgen Moltmann. This notion came to Moltmann by the writings of the Jewish philosopher and theologian Abraham Joshua Heschel. For him divine pathos is the way of God's presence in the world, the divine concern about his creation. Theprophets had no ideas about God. The prophets suffered the divine pathos. Moltmann took the notion of heschelian pathos and through it interpreted the Easter drama of Jesus of Nazareth. The Trinity pathos is the Father's loveself-humiliating himself on His Son in order to, through the Spirit, be the Father of all those humiliated.

KEY-WORDS: Divine pathos, Suffering; Theopaty.

${ }^{1}$ Recebido em 10/05/2015. Aprovado em 10/10/2015.

${ }^{2}$ Doutor em teologia sistemático-pastoral pela PUC- Rio. Email: icirio@uol.com.br 


\section{Introdução}

O escopo da teologia de Jürgen Moltmann é amplo e variado. A abrangência de seus interesses teológicos inclui, entre outros, a teologia ocidental cristã, a tradição reformada na qual foi formado, a mística judaica e a teologia ortodoxa. Desta, por exemplo, hauriu muitas intuições que estão em sua concepção social da dinâmica trinitária. As fontes teológicas e filosóficas não cristãs também foram decisivas para a formação do seu pensamento. Boa parte de suas noções mais inovadoras vieram de autores não cristãos, como, por exemplo, Ernest Bloch e sua noção de esperança, Franz Rosenzweig e sua original compreensão da redenção, Abraham J. Heschel e sua noção de pathos divino.

O objetivo deste artigo é destacar a recepção da noção hescheliana de pathos divino na teologia de Moltmann. A tese de doutorado em Filosofia defendida por Heschel, na Alemanha, durante os anos de1930, teve como tema a análise da consciência profética segundo os relatos do profetismo literário bíblico. Nos anos 1960, Heschel expandiu e ressignificou o seu trabalho doutoral ao compor o livro The Prophets (2011). Para o teólogo judeu, o que profeta conhece e sabe de Deus não vem de abstrações lógicas ou silogismos quaisquer; o que sabe de Deus vem do encontro com a divina presença.

Os profetas nada sabem da essência de Deus. Os profetas apenas sofrem o pathos de Deus. Por isso, para Heschel, o axioma da impassibilidade divina é desastroso como linguagem para referir-se ao Deus do profetismo bíblico. Sofrendo o pathos divino, os profetas testemunham a transitividade do amor divino pelo ser humano. Não comunicam ideias sobre Deus, testemunham a radicalidade do cuidado divino revelado em seu pathos (HESCHEL, 2011). Não se pode entender o drama pascal na teologia moltmanniana sem a influência da noção de pathos hescheliana. Como na obra de Heschel, também na fortuna teológica de Moltmanno axioma da impassibilidade divina recebeu profundo questionamento. Se Heschel o fez para mostrar a insuficiência de tal noção como espelho da consciência profética de Deus, em Moltmann, o questionamento se dá para mostrar a absoluta inadequeção de tal concepção como espelho da história de Jesus de Nazaré.

Para Heschel, a vida de Jesus de Nazaré é a história de um pathos ao mesmo tempo em que é o pathos de uma história. Tal expressão traduz a essência da cristologia trinitária de Moltmann e a aproxima radicalmente da noção de pathos divino em Heschel.

Se para Heschel a noção de pathos é marcada pela bipolaridade Deus/povo, em Moltmann, ela é tripolar: Deus/Jesus de Nazaré/povo. Portanto, Moltmann acrescentou um terceiro elemento: Jesus de Nazaré. Reinterpretou a noção de pathos à luz do evento pascal e enfatizou o sofrimento divino como fonte de sentido para o sofrimento humano. O sofrimento divino tem a ver com a afetação sofrida pela dinâmica trinitária na entrega do Pai, no Filho e no distanciar-se deste no Espírito.

Na dinâmica trinitária, o acento se volta para o dor do Pai, o escândalo da morte do Filho aos olhos do Pai, da separação do Pai, no Espírito, do Filho do seu amor. Tal

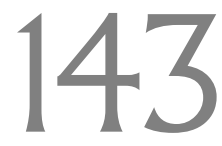


deslocamento da perspectiva bipolar para uma mais triádica cumpre, em Moltmann, a necessidade de um acento na dor divina para ressaltar a identificação do Pai com os horrores da condição humana. A seguir, apresentaremos noção de pathos divino conforme aparece no pensamento de J. Moltmann.

\title{
1. Pathos divino e bipolariadade Deus/povo
}

Em pelo menos seis dos seus livros, Moltmann faz referência à noção de pathos divino hescheliana. Como Heschel, Moltmann abraçou a ideia de um Deus apaixonado, o que afetou não somente sua visão de Deus, mas também a sua visão cristológica e escatológica (JAEGER, 1997).

No tópico a "Experiência da vida humana do pathos de Deus" do capítulo seis do livro O Deus crucificado, Moltmann refere-se explicitamente ao legado hescheliano do pathos divino como fonte de sua teopatia. Escreve ele:

\begin{abstract}
Começamos afirmando que a adoção do conceito filosófico grego do 'Deus incapaz de sofrer' da igreja primitiva, gerou dificuldades na cristologia, as quais só a teologia mais recente procurou combater. Porém, antes que 'o Deus que sofre' se tornasse o tema da teologia cristã no presente, a teologia judaica já estava discutindo esse assunto. A teologia cristã não pode fazer nada além de aprender com essa nova exegese judaica da história de Deus no Antigo Testamento e no sofrimento presente do povo judeu (MOLTMANN, 2011, p. 339).
\end{abstract}

No livro Trindade e Reino de Deus (2000), Moltmann reconhece em Abraham Heschel o primeiro a descrever a proclamação dos profetas como teologia pática.

Um dos primeiros a contestar expressamente a teologia do Deus apático foi Abraham Joshua Heschel. Afastando-se da filosofia religiosa judaica influenciada pelo helenismo - de Fílon, JehudaHalevi, Maiomônidese Espinoza, chamou a teologia dos profetas do Antigo Testamento de "teologia do pathos divino" (MOLTMANN, 2000, p. 39).

Moltmann resume a compreensão hescheliana do pathos divino:

No seu pathos, o Todo-poderoso sai de si mesmo. Dirige-se ao povo de sua eleição. Apresenta-se como parceiro da aliança com esse povo. Nesse pathos pelo seu povo, que leva o seu nome e representa a sua glória no mundo, o Todopoderoso é pessoalmente afetado pelas peripécias de Israel, por seus feitos, pecados e sofrimentos. Na comunhão da sua aliança com Israel, deus se torna passível. Sua existência e a história do povo estão ligados pelo pathos divino. A criação, a libertação, a aliança, a história da salvação nascem do pathos de Deus. (MOLTMANN, 2000, p.39)

Segundo Moltmann o sentido de pathos em Heschel não tem uma conotação psicológica, senão teológica. Ou seja, mais do que se referir aos humores divinos na conflituosa relação com o povo, a ideia de pathos quer acentuar a transigência do amor divino pela sua criação, o interesse divino nas questões humanas, o envolvimento de Deus na história, o engajamento divino no destino do seu povo.

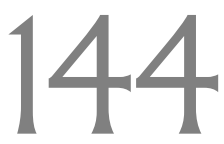


Por certo, as representações de Javé como amigo, como pai, como mãe, como amante enganado de Israel são imagens tão antropomórficas quanto as de um Deus zeloso, ciumento, irado ou sedento de amor. Quem quer sustentar que só a apatia é "conforme Deus" não compreende o que dizem essas imagens (MOLTMANN, 2000, p. 40).

Portanto, a categoria de pathos, quando tomada como ponto de partida para pensar a presença do Deus Vivente na criação, abre as portas para a possibilidade de entendê-lo não em sua essência, mas em sua paixão e envolvimento com a história. Assim sendo, segundo Moltmann: aprende-se a historicidade de Deus (MOLTMANN, 2000, p. 40).

E, dado que a experiência vital do ser humano se dá na dinâmica da sua experiência divina, pode-se, segundo Moltmann, concordar com Heschel quando propõe uma existência simphatética, em contrapartida ao ideal estóico de um homo apatheticus. Ou seja, a experiência do pathos divino abre o ser humano para as alegrias e tristezas da vida, pois ele "ama em comunhão com o amor de Deus, zela pela glória de Deus, ira-se com a ira de Deus, sofre com os sofrimentos do seu Deus, para finalmente ser feliz na beatitude divina" (MOLTMANN, 2000, p. 40).

De acordo com Moltmann, Heschel desenvolveu sua teologia do pathos divino como uma teologia bipolar. Ou seja, em si mesmo Deus é livre, não estando submetido ao destino. Mas, movido por sua paixão, entra em aliança. É, por isso mesmo, o Deus dos deuses ao mesmo tempo queé Deus aliado do pequeno povo de Israel. Deus reina no céu e acha-se entre os seres inferiores da terra. É Deus dos deuses fazendo justiça aos órfãos e às viúvas. Encontra-se com os homens no limitado, depreciado e pequeno (MOLTMANN, 2000, p. 40). Uma segunda bipolaridade teria a ver com o binômio responsivo: pathos divino/simpatia do ser humano. Ou seja, "ao pathos pelo qual Deus sai para fora de si, responde a simpatia do espírito, que procede de Deus" (MOLTMANN, 2000, p. 41).

Moltmann recorre à teologia rabínica e à doutrina cabalística da shekhináh, segundo as quais haveria um determinado número de estágios na auto-humilhação divina, que seriam uma espécie de acomodações de Deus aos limites da história humana (MOLTMANN, 2011, p.347). Em sua shekhináh, o santo de Israel compartilha os sofrimentos e a redenção deste, de modo que, neste sentido, pode-se dizer: Deus redime a si mesmo no Egito juntamente com seu povo. Libertação de Israel significa, pois, libertação dessa inabitação de Deus do sofrimento que a causa (MOLTMANN, 2000, p. 41).

Ou seja, o que Heschel chamou de pathos divino Moltmann, na linha da mística cabalística judaica, entende como sendo as acomodações e humilhações de Deus nos limites da história do mundo. Acomodações expressas na criação, na escolha dos patriarcas, na aliança com o povo, no sofrimento no exílio: todas como formas de autohumilhação de Deus (BAUCKHAM, 2006, p. 57).

Um exemplo forte e comovedor da auto-humilhação divina, conforme a teologia rabínica, estaria no relato de E. Wiesel, sobrevivente de Auschwitz:

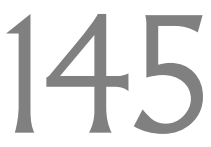


A SS assassinou dois homens judeus e um jovem diante de todos no campo de concentração. Os homens morreram rapidamente; a agonia do jovem durou meia hora. Onde está Deus? Onde está Deus? perguntou alguém atrás de mim. Depois de longo tempo, quando ainda o jovem continuava sofrendo, enforcado por um laço, outra vez ouvi o homem dizer: Onde está Deus, onde está Deus? E em mim mesmo escutei a resposta: Onde está? Aqui... está ali pendurado no patíbulo... (MOLTMANN, 2011, p. 348).

Para Moltmann, qualquer outra resposta seria blasfêmia. No contexto de Wiesel, falar de um Deus impassível o converteria em um demônio. Por outro lado, falar de um Deus absoluto, converteria-o em um nada destruidor. Falar, aqui, de um Deus indiferente, condenaria os homens à indiferença. O mais importante desta teologia patética é, precisamente, a possibilidade que oferece de interpretar a história dos sofrimentos do povo judeu e a história de seus mártires como história dos próprios sofrimentos da shekhináh divina (MOLTMANN, 2011, p. 349).

Segundo Moltmann, a história da shekhináh é a historia da alienação de Deus, do seu autoexílio, da sua auto-humilhação pela qual o Todo-poderoso sai de si mesmo e vai ao encontro do mundo finito, à procura do humano, feito à sua imagem e semelhança. O amor pelo ser humano criado livre, constitui "a base mais profunda da autodistinção de Deus, da bipoloaridade divina, da entrega espontânea de Deus" (MOLTMANN, 2000, p. 43).

\section{Da bipoloaridadeà perspectiva trinitária}

À diferença de Heschel, porém, para quem a bipolaridade é tão cara à noção de pathos, Moltmann acrescenta um terceiro elemento. Segundo o teólogo alemão, a controvérsia rabínica sobre a auto-humilhação de Deus parece conduzir a uma distinção não apenas entre Deus e o povo da aliança, mas também entre o próprio Deus e sua morada, a shekhináh, entre Deus e o Espírito de Deus que habita em nós (DIBITONTO, 2007, p. 48). Pergunta Moltmann: "A shekhináh que vagueia com Israel pela poeira das ruas e é pendurada nas forcas de Auschwitz, sofre no Deus que tem os confins da terra em suas mãos?" (MOLTMANN, 2011, p. 349). Se assim for, o sofrimento afetaria o pathos de Deus não apenas externamente, mas também internamente.

Se de fato a noção rabínica de shekhináh inclui as ideias de inabitação do Senhor no meio do seu povo, de rebaixamento do Eterno e de antecipação da glória daquele que vem, então, há uma afinidade entre tal noção e a noção trinitária cristã, interpretando-se o Pai como aquele que se abaixa, encarnando-se no Filho e constituindo-se como Pai;o Filho como aquele que antecipa a glória do Pai, constituindo-se como Filho e o Espírito como aquele que inabita a criação remetendo-a ao seu futuro escatológico, constituindo-se como

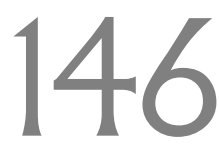


Espírito. Em todas essas dimensões, está o amor que abraça o sofrimento (DIBITONTO, 2007, p. 48).

Moltmann, sob o signo da teologia patética de Heschel, vê em Orígenes um dos poucos autores da Igreja antiga a aprofundar a relação Deus e sofrimento. $\bigcirc$ mérito deste padre da Igreja grega estaria exatamente em implicar a perspectiva trinitária ao referir-se ao sofrimento de Deus. Para Orígenes, o sofrimento de Deus sustenta o mundo, suportando sua carga. É o sofrimento do Pai, que ao entregar seu próprio Filho, experimenta a dor da redenção. É o sofrimento do Filho de Deus, que carrega em si nossos pecados e nossas fraquezas:

Ao falar do sofrimento de Deus, Orígenes tem em mente o sofrimento aceito por amor, a simpatia que está encerrada em toda a misericórdia autêntica. Quem se comisera participa no sofrimento alheio, toma sobre si sofrimento alheio, sofre por outros, entrando em sua comunhão e carregando seus fardos. Este sofrimento solidário, vicário, e remidor por meio de vicariedade é o sofrimento de Deus (MOLTMANN, 1996, p. 244-245).

Em Orígenes, a bipolaridade se manifesta no fato de que a paixão de Cristo é seu sofrimento por nós. Mas Orígenes dá um passo além de tal bipolaridade e o faz trinitariamente ao se referir a uma paixão que se produz entre o Pai e o Filho. Nesse sentido, "o sofrimento do amor não afeta somente a ação redentora extrinsecamente, senão a própria comunhão trinitária de Deus" (MOLTMANN, 2000, p. 43).

Portanto, o pathos de Deus que os profetas descobriram e anunciaram é o pressuposto para a compreensão cristã do Deus que se revela na paixão de Cristo. Os termos bipolares da teologia patética do judaísmo, quais sejam a aliança de Deus com o povo e a pertença a este povo, certamente, subjazem à compreensão cristã de Deus. Entretanto, há aqui um salto. Onde para Israel se fala da imediatez de Deus na aliança com seu povo, se fala, para o cristão, do Cristo que oferece a paternidade de Deus e a força do Espírito.

Por Cristo, Deus mesmo cria as condições para adentrar esta relação patéticosimpática. Por ele as cria para aqueles que não podem trazer consigo estas condições: para os pecadores, ímpios e abandonados de Deus. Por isso, do ponto de vista cristão, nenhuma relação com Deus por parte dos homens é imaginável desvinculada desta pessoa e sua história. E, na medida em que Deus mesmo cria as condições para a comunhão com ele mediante sua auto-humilhação na morte do crucificado e sua exaltação do homem no ressuscitar de Cristo, esta comunhão se faz algo gratuito, sem pressupostos quaisquer e universal para todos os homens em sua miséria comum (MOLTMANN, 2011, p. 350).

Conclui Moltmann: "Por isso, em razão da incondicionalidade e universalidade da gratuita comunhão com Deus, a teologia cristã tem que ser pensada ao mesmo tempo cristocêntrica e trinitariamente" (MOLTMANN, 2012, p. 351). Deus estava em Cristo: para Moltmann, isto representa a condição de comunhão com Deus por parte de pecadores e ímpios, "pois abre o espaço vital de Deus a todo o homem e a todos os homens". (MOLTMANN, 2011, p. 351). Vivemos em Cristo: eis a consequência para a fé, que experimenta a total comunhão com Deus na comunhão com Cristo.

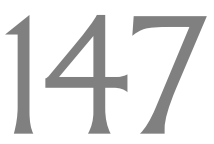




\section{A existência simpathética: paixão pela vida}

Para os seres humanos, nenhum aspecto de sua existência haverá de disfarçar-se na comunhão com Deus. Ao contrário, o ser humano pode desfazer-se de todas as aparências e "fazer-se neste Deus humano o que é em verdade". Para aproximar-se dele, não necessita de nenhuma justificativa nem tampouco acusações que destruam a si mesmo. "O abandonado por Deus e recusado pode aceitar-se a si mesmo ali onde se reconhece o Deus crucificado, que está com ele e já o tem aceito". Não há recusa que ele não tenha levado sobre si, não há sofrimento e morte que estejam longe de sua via crucis. Se Deus as levou sobre si, abre-se a possibilidade de aceitação da vida completa e verdadeira ao mesmo tempo em que da morte total e verdadeira (ALMEIDA, 2002).

Moltmann reconhece que, se entendidas panteísticamente, as afirmações acima nada mais seriam que variações daquele sonho que busca apagar da existência o negativo no mundo. Entretanto, "uma teologia trinitária da cruz percebe Deus no negativo, e, por isso mesmo, o negativo em Deus, sendo panenteísta e deste modo dialética”. Por isso, reconhecer Deus na cruz de Cristo significa também reconhecer em Deus o sofrimento sem saída. A morte e a recusa carentes de esperança. Conclui Moltmann:

Deus em Auschwitz e Auschwitz em Deus crucificado: este é o fundamento de uma esperança real, tanto transformadora como superadora do mundo e a base para um amor que é mais forte que a morte... Esta é a razão de viver com os medos da história e de seu final e, ainda assim, permanecer no amor e contemplar o vindouro sempre aberto ao futuro de Deus. É a base para viver em Deus conculpável e consofrente pelo futuro do homem (MOLTMANN, 2011, p. 399).

O teísmo metafísico propôs como tarefa ininterrupta eliminar da noção do amor de Deus qualquer elemento de reciprocidade. Deus jamais pode ser afetado pelos objetos do seu amor. Sofrimento, com todos os sentimentos que dessa fonte derivam, não pertence ao amor divino. $O$ entendimento de Moltmann é radicalmente diferente: $\mathrm{o}$ amor de Deus é sua paixão no duplo sentido de devoção apaixonada (Leidenschaft) e sofrimento (Leiden). Estes dois sentidos não estão separados, mas integrados como interesse passional que envolve a vulnerabilidade ao sofrimento e à morte (BAUCKHAM, 2006, p. 49).

Esta paixão é ela própria uma paixão pela vida, a qual leva ao sofrimento. Nesse sentido, como enfatiza Moltmann, o sofrimento de Deus é um sofrimento ativo. Ou seja, o amor apaixonado exige que o próprio Deus entre em uma relação recíproca com outros, na qual ele se dispõe a sofrer a ponto de doar e se dar por inteiro (TANG, 1996, p. 179).

Porque Deus é amor, a atividade econômica divina pode ser entendida como sendo determinada por sua vida imanente desde o começo. Em primeiro lugar, o amor de Deus é amor que se comunica de modo que Ele se dispõe a abrir-se ao mundo desde a eternidade. Em segundo lugar, o amor de Deus é amor apaixonado enquanto se dispõe a

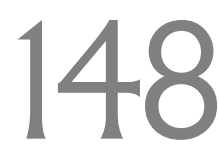


abrir-se ao mundo de uma forma dialética. $\bigcirc$ amor, a forma do pathos divino, apresentase aqui não como atividade para outros, mas envolvimento com outros. Pathos não é uma deficiência do amor humano, o qual deve ser eliminado do conceito do amor divino; é, outrossim, a grandeza do amor, sem o qual ele não é um amor reconhecível (BAUCKHAM, 2006, p. 50).

\section{Conclusão}

Moltmann herdou de Heschel a noção de pathos divino. Em boa parte dos seus escritos cuidou de descontruir a noção de Theosaphatés, mostrando a insuficiência de tal noção como aproximação da paixão de uma história, ou da história de uma paixão, o evento Jesus de Nazaré. Também como Heschel, construiu sua teologia sob a sombra do horror da Segunda Guerra Mundial, o horror do holocausto. Descobriu nestes horrores a sombra do Gólgota, o grito de Jesus como ferida aberta de toda teologia. Sob a noção de pathos, ressignificou o sofrimento humano como expressão do sofrimento divino, consofrente e conculpável, do Pai que, no Filho, abraça, pelo Espírito, os horrores da história.

Abraçou a noção hescheliana de pathos divino, colocando-a no centro do drama pascal de sua cristologia. Na tradição mística e rabínica, viu as sementes do pathos na ideia da shekhináh. Percebeu nela uma autodistinção no interior do Vivente, o sofrimento no coração do Pai. Resignificou, pois, a noção bipolar do pathos profético à luz da concepção trinitária. É de se perguntar aqui se tal passagem de uma concepção bipolar do pathos para uma concepção trinitária não é ela mesma, tal passagem, um resquício do teísmo metafísico que Moltmann tanto critica. Com outras palavras, o caráter binário da experiência do pathos, na filosofia ou teologia profunda de Heschel, não perde sua carga bíblica, existencial e histórica, quando a noção trinitária, nascida como conceito teológico em contexto do extemporâneo ao do imaginário bíblico, faz uma entrada no drama do pathos divino?

Sem desconsiderar tais questionamentos, é indiscutível a força da teologia patética moltmanniana em abrir a teologia cristã para uma nova concepção de Deus para além do teísmo metafísico. A vida do ser humano em sua historicidade profunda, ganha também, pela via da patética hescheliana, grande carga existencial e salvífica. Não é por acaso que muitas teologias do século $X X$, reconheçam parte de seu DNA na teologia patética de Moltmann: a teologia da libertação, inclusive. Também não é por acaso que a tempiterna questão da teodiceia encontre na teologia patética moltmanniana um dos seus sustentáculos teóricos mais fortes.

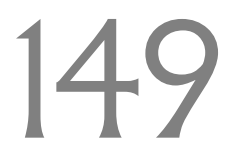




\section{Referências Bibliográficas}

ALMEIDA, Edson Fernando. Do viver apático ao viver simpático: sofrimento e morte. São Paulo: Loyola, 2006.

BAUCKHAM, R. The Theology of Jürgen Moltmann. London: T\&T Clark, 2006.

HESCHEL, Abraham J. The Prophets. New York: Perennial Classics, 2011.

JAEGER, John David. Abraham Heschel and the theolgogy of Jürgen Moltmann. In: Perpectives in ReligiousStudies.24, Sum, p. 167-179, 1997.

MOLTMANN, J. Experiências de reflexão teológica: caminhos e formas da teologia cristã. São Leopoldo: Unisinos, 2004.

. O Deus crucificado. São Paulo: Academia cristã, 2011

. O caminho de Jesus Cristo. Petrópolis, Vozes, 1996.

. Quem é Jesus Cristo para nós hoje? Petrópolis, Vozes, 1997

. Trindade e Reino de Deus.Petrópolis: Vozes, 2000.

. Vastospazio: Storia di unavita.Brescia: Queriniana, 2009.

. The Prophets. New York: Perennial Classics, 2011

TANG, S. K. God's History in the Theology of Jürgen Moltmann. Bern/New York: P. Lang, 1996.

DIBITONTO, Daria. Jürgen Moltmanntra teologia e filosofia.Torino: Trauben, 2007. 